\title{
NOTES
}

\section{Identification of a Carbon Monoxide-Metabolizing Bacterium as a Strain of Rhodopseudomonas gelatinosa (Molisch) van $\mathrm{Niel} \dagger$}

\author{
M. P. DASHEKVICZ AND R. L. UFFEN \\ Department of Microbiology and Public Health, Michigan State University, East Lansing, Michigan 48824
}

Strain 1, a bacterium which grew methylotrophically with carbon monoxide under anaerobic, dark conditions, was identified as a member of Rhodopseudomonas gelatinosa (Molisch) van Niel on the basis of its cell morphology, ultrastructure, pigment content, and nutritional properties.

Strain 1 , a facultatively methylotrophic bacterium according to the definition suggested by Colby and Zatman (1), was originally identified as a member of Rhodopseudomonas (9). The cells of this strain grew in the absence of light under an oxygen-free, $100 \%$ CO atmosphere and used the gas as the sole carbon and energy substrate. Data in this report show that this COutilizing bacterium is a strain of Rhodopseudomonas gelatinosa.

Cells of strain 1 were gram negative and exhibited dimensions of 0.3 to $0.4 \mu \mathrm{m}$ by 2.6 to 3.0 $\mu \mathrm{m}$. The slightly bent, rod-shaped cells multiplied by binary fission. During anaerobic growth with $\mathrm{CO}$, strain 1 occurred as single, actively motile, polarly flagellated cells which contained small amounts of carotenoids and a bacteriochlorophyll $a$ concentration of $7.8 \mathrm{nmol} / \mathrm{mg}$ of protein, as reported earlier (9). When the cells were placed in white light (at about $8.0 \times 10^{3}$ ergs $/ \mathrm{cm}^{2}$ per s) under argon gas, instead of $\mathrm{CO}$, and in the growth medium described by Weckesser et al. (13), the bacteriochlorophyll $a$ content increased to $30 \mathrm{nmol} / \mathrm{mg}$ of protein, and yellowish-brown cell material was formed. During photosynthetic growth under this condition, strain 1 produced large amounts of slime and formed macroscopic cell aggregates. In addition to similarities in general cell morphology and ability to produce slime during anaerobic growth in the light, strain 1 closely resembled ATCC 17011, the neotype strain (6) of $R$. gelatinosa, in other ways. Both cell types exhibited similar intracytoplasmic photosynthetic membrane structures, contained the same type of photochemically active pigments, and had clearly similar nutritional properties. The guanine-plus-cy-

† Journal article no. 8685 of the Michigan Experiment Station. tosine content of strain 1 deoxyribonucleic acid was not determined. It appeared that samples of its deoxyribonucleic acid contained a component(s) which formed an aggregate with standard deoxyribonucleic acids and interfered with the guanine-plus-cytosine determinations, which involved buoyant density centrifugation (M. Mandel, personal communication). $R$. gelatinosa ATCC 17013 and ATCC 17014 and $R$. gelatinosa DR-2 (3) were also used in a few experiments in this study, as indicated below.

Rhodopseudomonas sp. strain 1 and $R$. gelatinosa ATCC 17011 showed similar ultrastructure after the cells were grown under anaerobic conditions in the light. Figure $1 \mathrm{~A}$ is a photomicrograph of a thin section of a cell of strain 1 which exhibited tubular, or finger-like, intrusions of the cell membrane into the cytoplasm (Fig. 1B). These membrane intrusions have been reported elsewhere $(2,13)$ to be the typical photosynthetic membrane apparatus in $R$. gelatinosa, and they are shown for ATCC 17011 in Fig. 1C. In addition to possessing the same type of photosynthetic membranes, strain 1 and $R$. gelatinosa ATCC 17011 exhibited virtually identical light absorption properties. After anaerobic growth in the light, whole cells of strain 1 and ATCC 17011 were suspended in sucrose solution (5), and the light absorption properties of the cells were determined with a Beckman recording spectrophotometer (model DK-2). The cells of both strains exhibited absorption maxima at 870 , 800,595 to 597 , and $382 \mathrm{~nm}$, which are characteristic of bacteriochlorophyll $a$ (7). In the Soret region, the spectral properties of both strains were also identical and showed primary absorbance maxima at 525 and $472 \mathrm{~nm}$. These spectral data and the observation that phototrophically grown strain 1 cell material exhibited a reddish- 


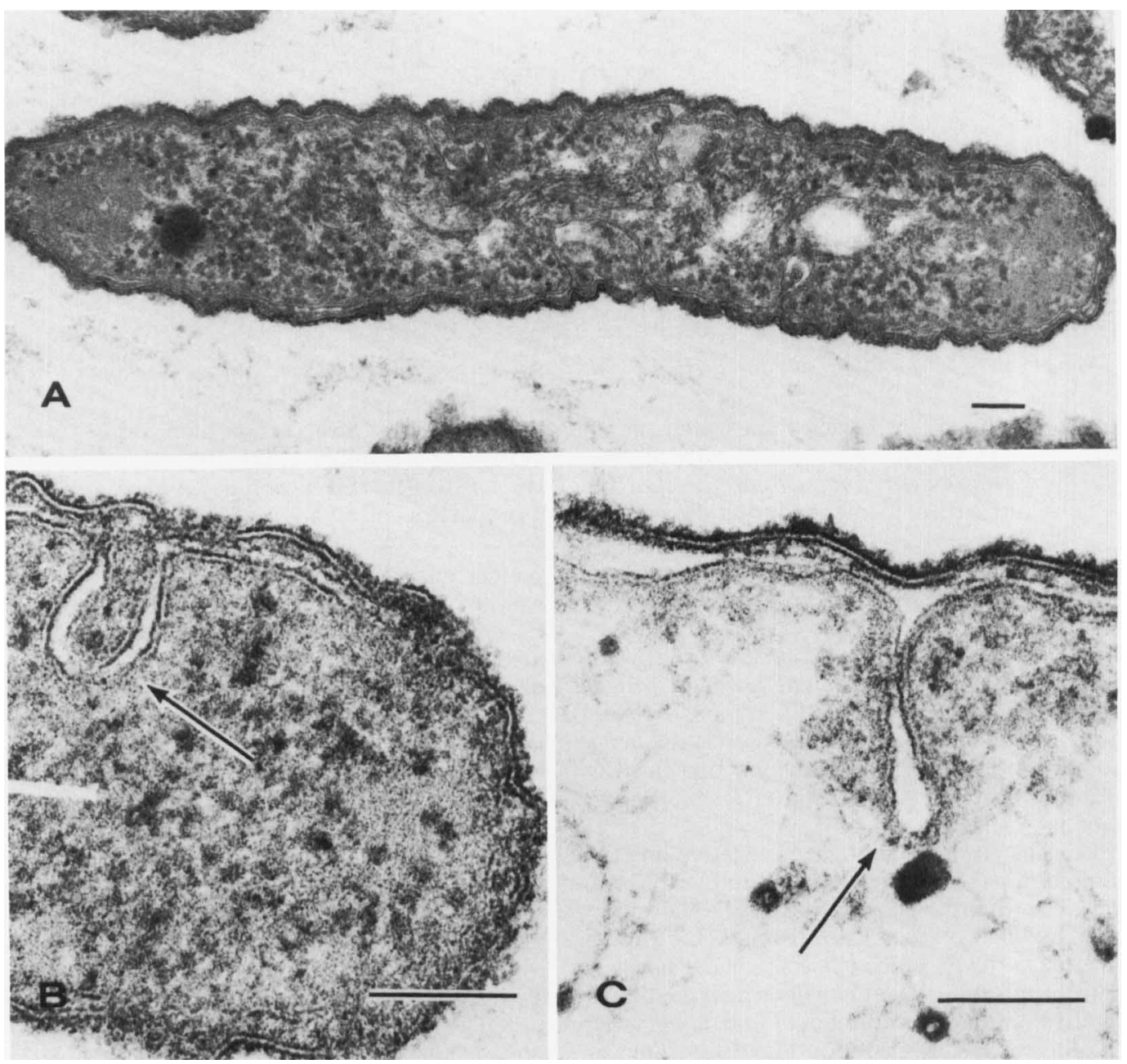

FIG. 1. Electron micrographs of thin sections of cells of Rhodopseudomonas sp. strain 1 and R. gelatinosa ATCC 17011 after photosynthetic growth. Cells were fixed with glutaraldehyde $(2.5 \%$, wt/vol) followed by osmium tetroxide. Thin sections were stained with uranyl acetate and lead citrate before electron microscopic examination with a Phillips 300 EM transmission electron microscope. (A) Longitudinal thin section of a photosynthetically grown strain 1 cell. (B) Finger-like invagination (arrow) of the cell membrane in a lightgrown cell of strain 1. (C) Finger-like cell membrane invagination (arrow) in R. gelatinosa ATCC 17011; the invaginated membrane represents the photosynthetic membrane system $(2,13)$. Bars correspond to $0.1 \mu \mathrm{g}$.

purple color change during exposure to air suggested that the cells, like those of $R$. gelatinosa ATCC 17011, contained carotenoids of the group 2 type (7).

In a different series of experiments, the nutritional properties of strain 1 were compared with those of other $\boldsymbol{R}$. gelatinosa strains. Like all $\boldsymbol{R}$. gelatinosa cells (13), strain 1 liquefied gelatin during photosynthetic growth. It was also determined that, during photosynthetic metabolism, strain 1 required both biotin and thiamine, the same as other $R$. gelatinosa strains (13). Strain 1 could utilize amino acids, ammonium salts, or molecular $\mathrm{N}_{2}$ as a nitrogen source during development in the light. After growth in a medium (4) containing malate and glutamate as the only nitrogen sources, both strain 1 and $R$. gelatinosa ATCC 17011 exhibited nitrogenase activity, indicated by the acetylene reduction test (8). Additional chemical compounds photometabolized by strain 1 and $R$. gelatinosa 17011 and the amounts of bacteriochlorophyll $a$ produced by the cells during growth with the substrates are presented in Table 1 . Both strains showed abundant growth with several different amino acids and sugars and with pyruvate. (Sodium pyruvate 
added to a complex medium with yeast extract and peptone [11] and maintained under argon gas also supported anaerobic growth in the dark, as was the case with all $R$. gelatinosa strains used in this study. The pyruvate fermentation reactions in the cells, however, were not identified.) In the light, both strain 1 and $R$. gelatinosa ATCC 17011 exhibited good growth in a medium with malate, but only ATCC 17011 could utilize citrate (Table 1). It should be noted that, although photometabolism of citrate is not a general property of $R$. gelatinosa (13), this clear distinction between strain 1 and $R$. gelatinosa ATCC 17011 was important when the CO-dependent growth response of the cells was tested.

Conditions for CO-dependent growth of strain 1 have been described elsewhere (9), and the ability of the cells of this strain to grow either

TABLE 1. Photometabolism of different carbon compounds by $R$. gelatinosa

\begin{tabular}{|c|c|c|}
\hline \multirow{2}{*}{ Substrate $^{a}$} & \multicolumn{2}{|c|}{ Growth response $^{h}$} \\
\hline & Strain 1 & ATCC 17011 \\
\hline $\mathrm{CO}_{2}+\mathrm{H}_{2}(50: 50) \ldots$ & - & - \\
\hline Formate & $+(2.3)$ & $+(5.8)$ \\
\hline$\ldots \ldots \ldots$ & $++(7.0)$ & - \\
\hline Propionate . . . . . . & $+(1.8)$ & - \\
\hline Butyrate ............. & - & - \\
\hline Valerate & - & - \\
\hline Aspartate & $+++(8.5)$ & $+++(6.9)$ \\
\hline Asparagine $\ldots \ldots \ldots$ & $+++(3.3)$ & $+++(7.4)$ \\
\hline Alanine . . . . . . . . & $+++(2.8)$ & $+++(4.8)$ \\
\hline Glutamate . . . . . . & $+++(2.3)$ & $+++(3.6)$ \\
\hline Tartrate ........... & - & - \\
\hline Acetone $\ldots \ldots \ldots$ & - & - \\
\hline Ethanol ..... & - & - \\
\hline Glycerol & - & - \\
\hline D-(-)-Mannitol $\ldots \ldots$ & - & - \\
\hline 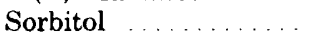 & $+++(5.0)$ & $+(6.4)$ \\
\hline Glucose ..... & $+++(4.3)$ & $++(6.0)$ \\
\hline Fructose $\ldots$ & $+++(2.7)$ & $+++(5.4)$ \\
\hline Pyruvate ... & $++(3.0)$ & $++(2.7)$ \\
\hline Malate ..... & $+++(4.0)$ & $+++(4.0)$ \\
\hline Citrate & - & $+++(2.8)$ \\
\hline
\end{tabular}

${ }^{a}$ The medium of Weckesser et al. (13) was prepared under strictly anaerobic conditions (11) with the appropriate carbon compound at a concentration of 20 $\mathbf{m M}$, unless otherwise indicated. Inoculated medium was incubated at $30^{\circ} \mathrm{C}$ under incandescent white light. The incident light intensity was $2 \times 10^{5} \mathrm{ergs} / \mathrm{cm}^{2}$ per $\mathrm{s}$.

${ }^{b}$ Growth response of cells after three successive transfers under anaerobic conditions in the light in medium of the same composition. At the end of each 7-day incubation period, freshly prepared medium (10 ml) was inoculated with approximately $10^{6}$ cells. Cell growth was evaluated as follows: optical density at 640 nm 0.0 to $0.05,-; 0.06$ to $0.2,+; 0.21$ to $0.40,++$; and 0.41 to $1.0,+++$. Numbers in parentheses are nanomoles of bacteriochlorophyll $a$ per milligram of protein in cell material. anaerobically in the dark with $\mathrm{CO}$ or in the light under an argon atmosphere was measured (unpublished data). In these experiments, cells grown in the dark and under $\mathrm{CO}$ appeared to metabolize equally well in the light with argon and formed typical yellowish-brown colonies. To obtain similar results when phototrophically grown cells of strain 1 were placed in the dark with $\mathrm{CO}$, however, it was first necessary to "condition" cells to CO before dark exposure. To accomplish this, phototrophically grown cells of strain 1 were spread onto the surface of a solid medium (9) which had been prepared in anaerobic bottles (11). The argon gas atmosphere in the anerobic bottles was changed to $\mathrm{CO}$, and the bottles were then placed into white light $(1.2 \times$ $10^{4} \mathrm{ergs} / \mathrm{cm}^{2}$ per s). After $12 \mathrm{~h}$ of incubation in the light, the bottles were regassed with $\mathrm{CO}$ and finally incubated in the dark, where the cells developed faintly pink-colored colonies. The same "training" regimen was used to test the ability not only of $R$. gelatinosa strains but also of Rhodopseudomonas sphaeroides ATCC 17023 , of one strain of Rhodopseudomonas palustris, of Rhodopseudomonas capsulata strains $6950, \mathrm{KBI}(12)$, and ATCC 23782 , and of Rhodospirillum rubrum strain $S_{1}$ and mutant $C(10)$ to metabolize and grow with $\mathrm{CO}$ under strictly anaerobic conditions in the dark. The results showed that, of the $R$. gelatinosa strains examined here, only ATCC 17011 exhibited CO-dependent growth in the dark. During this growth photosynthetic pigment synthesis was repressed and a uniformly turbid cell suspension was produced, but the strain only reached a density of $1.3 \times 10^{9}$ cells per ml (about one-fifth the cell density obtained by strain 1). Furthermore, after ATCC 17011 was adapted for CO-dependent metabolism, the dark-grown cells grew equally well when they were placed back into the light and, unlike strain 1, showed excellent growth with citrate (Table 1). In addition to $R$. gelatinosa ATCC 17011, the only other phototrophic bacteria studied which showed CO-dependent growth in the dark were $R$. rubrum strains $S_{1}$ and $C$. Resting suspensions of these cells rapidly oxidized $\mathrm{CO}$ to $\mathrm{CO}_{2}$ and produced $\mathrm{H}_{2}$ in the dark, but the cell growth response with $\mathrm{CO}$ was extremely slow.

Although our results indicated that, in addition to strain 1, only one (ATCC 17011) of four $R$. gelatinosa strains tested was able to grow anaerobically with $\mathrm{CO}$ in the dark, we concluded that strain 1 is a member of $R$. gelatinosa based on the cellular morphology of the strain, its whole-cell light absorption spectrum, and the nutritional properties of the cells in anaerobic conditions in the light (Table 1) and in the dark with pyruvate. 
We are grateful to F. J. Stevens and S. H. Pankratz for the electron micrographs.

This research was sponsored by National Science Foundation grant PCM 76-81483 and Public Health Service grant GM 24672 from the National Institute of General Medical Sciences.

\section{REPRINT REQUESTS}

Address reprint requests to: Dr. R. L. Uffen, Department of Microbiology and Public Health, Michigan State University, East Lansing, MI 48824.

\section{LITERATURE CITED}

1. Colby, J., and L. J. Zatman. 1972. Hexose phosphate synthase and tricarboxylic acid-cycle enzymes in bacterium 4B6, an obligate methylotroph. Biochem. J. 128; 1373-1376.

2. de Boer, W. E. 1969. On ultrastructures in Rhodopseu. domonas gelatinosa and Rhodospirillum tenue. Antonie van Leeuwenhoek J. Microbiol. Serol. 35:241-242.

3. Klemme, J.-H. 1968. Untersuchungen zur Photoautotrophie mit molekularem Wasserstoff bei neuisolierten schwefelfreien Purpurbakterien. Arch. Mikrobiol. 64: 29-42.

4. Orm6rod, J. G., K. S. Ormerod, and H. Gest. 1961. Light-dependent utilization of organic compounds and photoproduction of molecular hydrogen by photosynthetic bacteria; relationships with nitrogen metabolism. Arch. Biochem. Biophys. 94:449-463.

5. Pfennig, N. 1969. Rhodopseudomonas acidophila, sp. n., a new species of the budding purple nonsulfur bacteria. J. Bacteriol. 99:597-602.

6. Pfennig, N., and H. G. Trüper. 1971. Type and neotype strains of the species of phototrophic bacteria maintained in pure culture. Int. J. Syst. Bacteriol. 21:19-24.

7. Pfennig, N., and H. G. Trüper. 1974. Order I. Rhodospirillales Pfennig and Trüper 1971, p. 24. In R. E. Buchanan and N. E. Gibbons (ed.), Bergey's manual of determinative bacteriology, 8th ed. The Williams and Wilkins Co., Baltimore.

8. Postgate, J. R. 1972. The acetylene reduction test for nitrogen fixation, p. 343-356. In J. R. Norris and D. W. Ribbons (ed.), Methods in microbiology, vol. 6B. Academic Press Inc., New York.

9. Uffen, R. L. 1976. Anaerobic growth of a Rhodopseudomonas species in the dark with carbon monoxide as sole carbon and energy source. Proc. Natl. Acad. Sci. U.S.A. 73:3298-3302.

10. Uffen, R. L., C. Sybesma, and R. S. Wolfe. 1971. Mutants of Rhodospirillum rubrum obtained after long-term anaerobic dark growth. J. Bacteriol. 108: 1348-1356.

11. Uffen, R. L., and R. S. Wolfe. 1970. Anaerobic growth of purple nonsulfur bacteria under dark conditions. J. Bacteriol. 104:462-472.

12. Weaver, P. F., J. D. Wall, and H. Gest. 1975. Characterization of Rhodopseudomonas capsulata. Arch. Microbiol. 105:207-216.

13. Weckesser, J., G. Drews, and H.-D. Tauschel. 1969. Zur Feinstruktur und Taxonomie von Rhodopseudomonas gelatinosa. Arch. Mikrobiol. 64:29-42. 